Vol. 1, No. 2, Desember 2021: h. 170-199. DOI: 10.53088/jih.v1i2.207

E-ISSN: 2807-2995 https://journal.nurscienceinstitute.id/index.php/jih

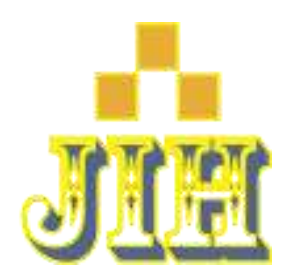

\title{
Dinamika Historis dan Distingsi Islam Asia Tenggara
}

\author{
Hairus Saleh, M.A \\ Alumni Sekolah Pascasarjana Universitas Islam Syarif Hidayatullah \\ sabdakhairus@mail.com
}

\begin{tabular}{|c|c|c|}
\hline Submited: & Revision Required: & Published: \\
29 Oktober 2021 & 21 November 2021 & 27 November 2021 \\
\hline
\end{tabular}

\begin{abstract}
Southeast Asia is an area where the majority of the population are muslim. The process of Islamization in Southeast Asia is peaceful. This is an inseparable part of the development of Islam in Southeast Asia. The topic of the history of Islam in Southeast Asia is a topic of discussion among historians to this day. The debate on the history of the emergence of Islam in the region focuses on the issue of the origin and development of Islam in the Southeast Asian archipelago. The emergence of Islam in Southeast Asia is a resurgence conditioned by history, political culture as well as the local and ethnic environment. Therefore, this paper wants to discuss the dynamics of the historical development of Islam in Southeast Asia.
\end{abstract}

Keywords: History, Islam, Southeast Asia 


\begin{abstract}
Abstrak
Asia Tenggara merupakan sebuah kawasan di mana mayoritas penduduknya memeluk agama Islam. Tidak bisa dipungkiri bahwa Islam masuk ke Asia Tenggara melalui jalan damai dengan prosesproses islamisasi. Hal itu, merupakan bagian yang tidak terpisahkan dari perkembangan Islam di Asia Tenggara. Topik mengenai sejarah Islam di Asia Tenggara menjadi perbincangan di antara para sejarawan hingga kini. Perdebatan mengenai sejarah munculnya Islam di kawasan tersebut terfokus pada isu tentang asal usul dan perkembangan Islam di kepulauan Asia Tenggara. Kemunculan Islam di Asia Tenggara merupakan kebangkitan yang dikondisikan sejarah, budaya politik serta lingkungan lokal dan etnis. Oleh sebab itu, makalah ini ingin membahas dinamika sejarah perkembangan Islam di Asia Tenggara.
\end{abstract}

Kata Kunci: Sejarah, Islam, Asia Tenggara

\title{
PENDAHULUAN
}

Sejarah Islam di Asia Tenggara menjadi topik diskusi di kalangan sejarawan, karena sejarah Islam Asia Tenggara merupakan sejarah laut, yang disebarkan secara cair ke dalam jantung kebudayaan masyarakat Nusantara, melebur, menyatu dalam satu tradisi hidup yang menghidupkan masyarakat di wilayah ini. terlepas dari kontroversi sejarah tentang awal mula perjumpaan Islam dan Masyarakat. Perjumpaan itu telah melahirkan satu entitas Muslim baru yang memiliki karakter tersendiri, berbeda dengan Muslim lain di belahan dunia lainnya. ${ }^{1}$ Sehingga Islam dan Masyarakatnya adalah satu kesatuan yang tak terpisahkan. Islam telah menjadi ikon kewilayahan dan kemasyarakatan di wilayah ini, khususnya negaranegara di wilayah kepulauan. ${ }^{2}$

\footnotetext{
1 Kedewasaan masyarakat dalam menerima ajaran agama, diduga oleh Noerhadi Magetsari, bahwa jauh sebelum hindu, budha, dan Islam hadir di wilayah Nusantara, telah ada "agama" yang dianut masyarakat dan mempengaruhi cara mereka menerima dan beragama setelahnya. Noerhadi Magetsari, Perspektif Arkeologi Masa Kini dalam Konteks Indonesia (Jakarta: Kompas, 2016), h. 131

2 Klasifikasi negara-negara kepulauan (archipelago) dan daratan (mainland) menjadi penting untuk membahasa sejarah Islam di Asia Tenggara. Sebagaimana diungkapkan di awal bahwa Sejarah Islam di wilayah ini adalah sejarah laut, di
} 
Pembahasan mengenai sejarah Islam di Asia Tenggara memiliki signifikansi yang sangat kuat, kita tidak bisa menjelaskan dinamika masyarakat Islam secara utuh, tanpa melibatkan masyarakat di Asia Tenggara, sebagaimana kita tidak bisa menjelaskan Asia Tenggara tanpa melibatkan dinamika Islam yang menghiasi sepanjang sejarah negara-negara di wilayah ini. Sekalipun demikian, wilayah ini tidak hanya dihuni oleh masyarakat Muslim saja, tapi terdapat ragam masyarakat, dengan tradisi, budaya, dan agama yang berbeda, sehingga perjumpaan lintas kebudayaan, tradisi, dan agama adalah hal yang niscaya, sebagaimana konflik, arogansi, dan dominasi satu kelompok masyarakat terhadap kelompok masyarakat lainnya sebagai akibat. Sekalipun, kontestasi etnik-agama, agama-agama, etnik-etnik terus berlangsung, jauh di atas itu, wilayah ini telah dikenal sebagai produsen masyarakat yang berkarakter cair, bertindak akomodatif, dan bersikap inklusif dalam melihat perbedaan.

Perkembangan Muslim di wilayah kepulauan lebih dinamis, dan mampu memainkan peran ekonomi dan politik dibandingkan Muslim di wilayah daratan (mainland). Sehingga pengkajian Islam kepulauan mendapat perhatian lebih, termasuk mengenai asal-usul kedatangannya.

\section{METODOLOGI}

Jika dilihat dari sumber datanya dapat dikatakan sebagai penelitian kepustakaan. Dikatakan sebagai penelitian kepustakaan karena penelitian ini mengkaji dinamika sejarah Islam di Asia tenggara melalui telaah terhadap naskah-naskah yang membahas tema tersebut. Sebagai mana dikatakan oleh Kun Zachrun Istanti bahwa penelitian kepustakaan dilakukan untuk mencari dan meneliti naskahnaskah, artikel-artikel ataupun sumber-sumber tertulis lainnya yang

mana Islam tersebar cepat melalui laut, dan berkembang pesat di kawasan pesisir. Namun, bukan berarti negara-negara daratan luput dari persebaran Islam, Islam di wilayah daratan memiliki sejarah yang dinamis, namun tidak seberkembang di wilayah kepulauan, sehingga cenderung luput dari perhatian sejarawan, sebagaimana Seddie Totiek menyatakan muslim yang terlupakan (forgotten Muslim) pada komunitas muslim champa di Vietnam dan Kamboja. Lihat, Seddik Taouti, "The Forgotten Muslims of Kampuchea and Viet Nam" dalam Ahmad Ibrahim, Sharon Siddique, dan Yasmin Hussain(ed), Reading on Islam in Southeast Asia (Singapore: Institute of Southeast Asian Studies, 1985), 193. 
ada hubungannya dengan masalah penelitian, baik yang tersimpan di perpustakaan maupun di museum. ${ }^{3}$

Dilihat dari perspektif analisisnya maka penelitian ini termasuk kepada penelitian kualitatif. Penelitian kualitatif menurut Subroto ${ }^{4}$ adalah metode pengkajian atau metode penelitian suatu masalah yang tidak didesain atau dirancang menggunakan prosedur-prosedur statistik. Sedangkan kalau dilihat dari tujuan penyelenggaraan penelitian ini dapat dikategorikan sebagai penelitian deskriptif analitik Penelitian deskriptif adalah penelitian yang dilakukan untuk memberi gambaran lebih detail tentang suatu gejala.

Penelitian menggunakan dua sumber data yaitu sumber data primer dan sumber data sekunder. Sumber primer dalam penelitian ini adalah Islam in Southeast Asia: Political, Social and Strategic Challenges for the $21^{\text {st }}$ Century karya Nathan, K.S. and Mohammad Hashim Kamali dan Islam and Civil Society In Souteast Asia karya Sharon Siddique and Omar Farouk Bajunid dan buku-buku lain yang berkaitan sebagai sumber sekunder dalam penelitian ini.

Pendekatan yang digunakan penelitian ini adalah pendekatan sejarah. Tujuannya adalah untuk mengkaji secara mendalam aspekaspek sejarah Islam di Asia Tenggara serta bukti-buktinya. Pendekatan sejarah dalam penelitian ini sangat penting untuk menganalisa bukti-bukti sejarah Islam di Asia Tenggara yang kemudian dianalisa untuk mendapatkan hasil yang mendalam.

\section{PEMBAHASAN}

\section{Sejarah Awal Kedatangan Islam}

Awal mula kedatangan Islam di Asia Tenggara memunculkan perdebatan panjang di antara para sejarawan yang mengkaji sejarah Islam di Asia Tenggara. Persoalan ini sangat dimaklumi, sebab pembicaraannya mengacu pada peristiwa yang terjadi berabad-abad lalu, yang memerlukan data-data sejarah untuk berspekulasi dan menginterpretasikan kejadian itu, bukan hanya cerita turun-temurun

\footnotetext{
${ }^{3}$ Kun Zachrun Istanti, Metode Penelitian Filologi dan Penerapannya, (Yogyakarta: Elmatera, 2010), h. 51.

4 Edi Subroto, Pengantar Metode Penelitian Linguistik Struktural (Solo: LPP dan UPT Penerbit dan Pencetakan UNS, 2007), h. 5.
} 
yang begitu banyak tersebar pada ingatan nenek moyang kita.

Perdebatan tentang awal mula hadirnya Islam di wilayah ini, setidaknya memunculkan beberapa teori, dengan banyak sejarawan yang saling mendukung dan saling membantah. Perdebatan itu berada pada beberapa pertanyaan pokok, kapan, di mana, dari mana, dan oleh siapa, Islam hadir ke Asia tenggara. Perdebatan ini, setidaknya dimulai pada abad ke-19. Ada beberapa teori tentang masuknya Islam ke kawasan Asia Tenggara, seperti teori kedatangan Islam ke Asia Tenggara dari India, Arab dan Persia.

Islam berasal dari India

Sejawaran yang mendukung teori ini, adalah J. Pijnappel, S. Keyzer, C.S. Hurgronje, J.P. Moquette, R.A. Kern. B.H.M Vlekke, J. Gonda, B.J.O. Schrieke, G.W.J Drewes, R.O. Winstedt, D.G.E. Hall, G.H. Bousquet. Mereka berargumen bahwa Islam datang ke wilayah ini pada abad ke-12, di mana argumennya disandar- kan pada keberadaan jalur perdagangan internasional, Mazhab, dan kemiripan batu nisan atau gaya penulisan antara sebagian wilayah India dan kepulauan Nusantara. Di antara pendukung teori ini, juga memunculkan secara spesifik dari wilayah mana di bagian India Islam di wilayah ini berasal, Pijnapel menduga dari Gujarat dan Malabar atas dasar kesamaan Mazhab; Hurgronje menduga dari Deccan di anak benua India sekitar abad ke-12; Moquette, menduga dari Gujarat atas dasar kesamaan batu nisan di Pasai dan Cambay; Fatimi, menduga dari Bengal, Morrison, menduga dari Koromandel pada akhir abad ke-13, dan membantah teori Gujarat dan Bengal atas dasar ketidaksesuaian masa, di mana ketika Raja Pertama kerajaan Islam Pasai wafat pada 1297, Gujarat masih kerajaan Hindu, barulah setahun kemudian ditaklukkan oleh penguasa Muslim.

Adapun beberapa bukti dari teori ini adalah ${ }^{5}$ :

- Terdapat batu marmar pada batu nisan yang mempunyai ciri buatan India, contohnya di batu nisan Raja Malik Pasai.

- Unsur budaya India amat dijumpai di Negara-negara Asia Tenggara

\section{Islam Asia Tenggara Berasal dari Arab}

\footnotetext{
${ }^{5}$ http://nugrahagalih.wordpress.com/2012/09/27muslim-di-asia-tenggara
} 
Teori ini dikemukakan oleh J. Crawfurd (1820), S. Keyzer (1859), G.K. Niemann (1861), J.J. Hollander (1861), P.J. Veth (1878), alAttas, dan beberapa sejarawan Indonesia. secara spesifik T.W Arnold (1913) menduga berasal dari Coromandel dan Malabar atas dasar kesamaan Mazhab dan terbukanya jalur perdagangan dari Coromandel ke Nusantara; Arnold juga Marrison tidak bisa memungkiri akan kemungkinan Islam berasal langsung dari Arabia, karena sebab Arabia telah sibuk dalam perdagangan lintas negara sejak abad $1 \mathrm{H}$, hal ini didukung oleh sumber-sumber China tentang adanya pedagang Arab menjadi pemimpin dalam pemukiman masyarakat Muslim di pesisir Sumatra; S. Keyzer menunjuk Mesir atas dasar kesamaan Mazhab yang berkembang dikedua wilayah; Niemann dan Hollander menunjuk Hadramaut; Naquib al-Attas yang memfokuskan kajiannya sejarah literatur yang berkembang di Nusantara, setelah abad ke-10, menyimpulkan bahwa literatur yang diproduksi oleh para ulama-ulama awal dipengaruhi oleh tradisi Arab dan bukan India; terakhir, pada1963 dilaksanakan seminar tentang Masuknya Islam ke Indonesia, yang kemudian menyimpulkan Islam masuk ke wilayah ini sejak abad $1 \mathrm{H}$ dan langsung berasal dari Arab. ${ }^{6}$

Adapun beberapa bukti dari teori ini yaitu:

- Telah ada perkampungan Arab di Sumatera (Barus) pada $625 \mathrm{M}$ (menurut literatur China Tingkok ${ }^{7}$.

- Persamaan penulisan dan kesusastraan Asia Tenggara dan Arab

- Karya-karya yang menceritakan pengislaman raja oleh Syeikh dari tanah Arab, misalnya hikayat raja-raja Samudera Pasai mengatakan Raja Malik diislamkan oleh ahli sufi dari Arab yaitu Syeikh Ismail.

\section{Teori Persia}

Teori ini didukung oleh P.A Hoesein Djajadiningrat, Abu Bakar Atjeh, dan M. Dahlan Mansur yang menaruh dugaan Islam berasal

${ }^{6}$ Azyumardi Azra, Jaringan Ulama Timur Tengah dan Kepulauan Nusantara Abad XVII \& XVIII, (Jakarta: Kencana, 2013), h. 2-18; Johan H. Meuleman, "The History of Islam in Southeast Asia : Some Questions and Debates" dalam K.S. Nathan dan Mohammad Hashim Kamali, Islam in Southeast Asia : Political, Social, and Startegic Challenges for the 21th Century (Singapore: Institute of Southeast Asian Studies, 2005), h. 23-24.

${ }^{7}$ Majalah Tauhid edisi 2/Th.1, Sya'ban 1433 H/Juli 2012 M. 
dari Persia atas dasar kesamaan tradisi dan kebudayaan yang hidup di beberapa wilayah di Nusantara, seperti peringatan Asyura, Sufisme Syekh Siti Jenar dan al-Hallaj, Pengejaan Huruf Arab. Kesamaan budaya tersebut sebagai bukti dari teori ini.

Namun teori ini dibantah oleh Saifuddin Zuhri dan Hamka. ${ }^{8}$ Pada wilayah Daratan, muncul juga argumentasi tentang awal mula kedatangan Islam, misalnya di Vietnam yang dulunya berada di bawah kekuasaan kerajaan Champa (abad ke-2 s/d 17) Islam masuk di wilayah kerajaan Champa pada abad ke-8, S.Q. Fatimi (1963) menduga bahwa Islam berasal dari Persia dan Arab. Maspero (1951) dan Ravaisse (1922) dengan menggunakan dokumen bergaya tulis Kufi, terdapat tulisan tahun 1025, 1035, dan 1039, dengan terjemahan bahasa Cham, keduanya menduga bahwa Muslim pada tahun itu telah terlibat dalam aktivitas politik, hukum, dan telah terlibat dalam interaksi dengan kerajaan. Hal ini masuk akal, sebab dahulu kerajaan Champa termasuk kerajaan yang menguasai jalur perdagangan di laut China selatan, yang telah menjadi jalur perdagangan internasional pada abad itu. ${ }^{9}$

\section{Cara-cara datangnya Islam di Asia Tenggara}

Masuknya Islam ke Asia Tenggara melalui cara-cara tertentu, sebagaimana menurut Uka Tjandrasasmita bahwa cara-cara tersebut melalui proses islamisasi di beberapa saluran yaitu ${ }^{10}$ :

\section{Saluran Perdagangan}

Pada tahap permulaan, proses masuknya Islam adalah melalui perdagangan. Kesibukan lalu lintas perdagangan pada abad ke-7 hingga ke-16 membuat pedagang-pedagang Muslim (Arab, Persia dan India) turut ambil bagian dalam perdagangan dari negeri-negeri bagian Barat, Tenggara dan Timur Benua Asia. Saluran Islamisasi

\footnotetext{
${ }^{8}$ Ahmad Mansur Suryanegara, Menemukan Sejarah : Wacana Pergerakan Islam di Indonesia (Bandung: Mizan, 1998), 90-94.

${ }^{9}$ Raymond Scupin, "Historical, Ethnographic, and Contemporary Analyses of the Muslims of Kampuchea andVietnam" dalam Journal of Social Issues in Southeast Asia, vol. 10, no. 2 (oktober 1995), download from 103.229.202.180, 30 Sep 2016. h. 305.

${ }^{10}$ Badri Yatim, Sejarah Peradaban Islam, (Jakarta: Raja Grafindo Persada, 2008), h201-204
} 
melalui perdagangan ini sangat menguntungkan karena para raja dan bangsawan turut serta dalam kegiatan perdagangan bahkan mereka menjadi pemilik kapal dan saham. Sehingga peradaban sedikit demi sedikit mulai berkembang, misalkan mereka berhasil mendirikan masjid-masjid.

\section{Saluran Perkawinan}

Dari sudut ekonomi, para pedagang Muslim memiliki status sosial yang lebih baik daripada masyarakat pribumi, sehingga penduduk pribumi terutama puteri-puteri bangsawan, tertarik untuk menjadi isteri saudagar-saudagar itu. Sebelum menikah mereka diislamkan terlebih dahulu. Setelah mereka mempunyai keturunan, lingkungan mereka makin luas, akhirnya terbentuklah perkampungan dan daerah-daerah bahkan kerajaan Muslim.

\section{Salarunan Tasawuf}

Dengan tasawuf, bentuk Islam diajarkan kepada penduduk pribumi mempunyai persamaan dengan alam pikiran mereka yang sebelumnya menganut agama Hindu, sehingga agama baru itu mudah dimengerti dan diterima. Ajaran mistik seperti ini masih dikembangkan di abad ke-19 M bahkan di abad ke-20 M.

\section{Saluran Pendidikan}

Islamisasi juga dilakukan dengan cara pendidikan, baik pesantren maupun pondok yang diselenggarakan oleh guru-guru agama, kiai-kiai dan ulama. Setelah keluar dari pesantren, mereka pulang ke kampung masing-masing atau berdakwah ke tempat tertentu dan mengajarkan Islam.

Saluran Kesenian

Saluran islamisasi melalui kesenian yang paling terkenal adalah pertunjukan wayang. Dikatakan bahwa Sunan Kalijaga adalah tokoh yang paling mahir dalam menentaskan wayang. Sebagian besar cerita wayang masih dipetik dari cerita Mahabrata dan Ramayana, tetapi dalam cerita itu disisipkan ajaran nama-nama pahlawan Islam. Kesenian-kesenian lainnya juga dijadikan alat islamisasi seperti sastra, hikayat, babad dan sebagainya.

Saluran Politik 
Pengaruh politik raja sangat membantu tersebarnya Islam di Asia Tenggara. Di samping itu, demi kepentingan politik, kerajaankerajaan Islam memerangi kerajaan-kerajaan non Islam. Kerajaan kemenangan kerajaan Islam secara politis banyak menarik penduduk kerjaan non muslim untuk masuk Islam.

\section{Kerajaan Islam di Asia Tenggara}

Aspek politik di wilayah Asia Tenggara memegang peranan penting dalam penyebaran Islam, di mana kerajaan sebagai pengendali kekuasaan politik dan memegang kendali seluruh aspek kehidupan masyarakat yang meliputi: tradisi, budaya, dan agama yang hidup dalam wilayah kekuasaanya. ${ }^{11}$ Perdebatan para sejarawan tentang asal-usul Islam berasal dari masa kerajaan-Samudera Pasaisekitar abad ke-12 dan ke-13, masa di mana data-data sejarah tentang kehadiran Islam sedikit lebih terang, dengan penemuan benda-benda arkeologi seperti batu nisan dan lainnya. Hampir semua sejarawan pengkaji Islam di wilayah ini, bersepakat bahwa penyebaran Islam berkembang pesat pada abad ke-13 dan setelahnya, ${ }^{12}$ masa ketika Islam telah terlembaga dalam institusi kerajaan. Proses pertemuan Islam dengan lembaga politik kerajaan hingga menjadi bagian integral dalam suatu kerajaan memiliki beberapa jalur pertemuan, misalnya perkawinan, perdagangan, dan hubungan politik.

Akibat pertemuan Islam dan Kerajaan, terjadinya konversi raja ke dalam Islam yang juga turut mengislamkan sistem dan masyarakat kerajaan. Perubahan sistem terkait dengan peralihan nama dari kerajaan ke kesultanan atau pemberian gelar sultan pada raja, dengan nama kerajaan tidak berubah kesultanan. Misalnya, Raja

\footnotetext{
11 "Agama Raja adalah Agama Rakyat" kalimat itu cukup mewakili, bagaimana raja memiliki peranan penting dalam keagamaan, termasuk dalam proses Islamisasi yang berlangsung di wilayah ini. namun, walau didahului dengan preferensi penyebaran Islam melalui konsep penaklukan, yang melibatkan perang antar kerajaan yang terjadi di beberapa wilayah di Timur Tengah dan Eropa, tapi pola ini tidak berlaku di kawasan Asia Tenggara, Islam disebarakan dengan cara yang cair melalui usaha diplomasi antar kerajaan, baik melalui hubungan bisnis dan perkawinan.

${ }^{12}$ Azyumardi Azra, Jaringan Ulama Timur Tengah dan Kepulauan Nusantara Abad XVII \& XVIII, h. 14-15
} 
Kerajaan Patani yang bernama Pya Tu Nakpa yang memeluk Islam dan berganti nama menjadi "Sultan Ismail Shah Zillullah fil A'lam" dan merubah nama Kerajaannya sebagai "Patani Daar al-Salam", yang kemudian turut mengislamkan para menteri dan rakyatnya; ${ }^{13}$ Kerajaan Gowa yang mengalami Islamisasi pada masa raja ke-14 (1593-1639) yang bernama "I Mangarangi Daeng Manrabia Sultan Alauddin Tominanga ri Gaukanna", raja-raja setelahnya menggunakan gelar Sultan. Islamnya raja Gowa turut diikuti oleh rakyatnya. ${ }^{14}$ Penguasa Pasai, Merah Silau yang juga berganti nama Sultan Malik al-Shalih.

Kerajaan-kerajaan Islam berperang penting dalam penyebaran Islam di wilayah ini. di bagian kepulauan disebut juga Asia Tenggara maritim sumber sejarah menyebutkan bahwa Islam hadir pertama kali ke wilayah Aceh dan Sumatera Utara di kepulauan Indonesia, yang kemudian diasumsikan bersamaan dengan Islamisasi di wilayah Malaysia, Brunei, Thailand, dan Filipina. ${ }^{15}$ Kerajaan-Kerajaan itu misalnya, Samudra Pasai di Utara Sumatera, kerajaan Patani di selatan Thailand, kerajaan Temasik (Singapura Lama), kesultanan Sulu dan Mindanao di selatan Filipina.

Kesultanan Sulu dikenal sebagai Kesultanan yang gencar melawan kolonialisme, dan mampu bertahan dalam dua kekuatan Kolonial Spanyol dan Amerika namun, kemudian tumbang pada tahun 1899 M setelah raja terakhir Sultan Jamaluddin Kiram wafat, kegencaran perlawanan Muslim Sulu Filipina Selatan melawan kolonialisme di Filipina demi mempertahankan agama dan tanah airnya terus berlangsung bahkan hingga saat ini, sehingga disebut sebagai "never ending-struggle".

\section{Masa Kolonialisme dan Imperialisme}

13 Ahmad Omar Chapakia,Politik Thai dan Masyarakat Islam di Selatan Thailand (Kuala Lumpur: Pustaka Darussalam Publishing, 2000) h. 18.

14 Prosesi pengislaman ini terjadi pada 22 September 1603 M bertepatan dengan malam Jumat, 9 Jumadil Awal $1015 \mathrm{H}$. Islamisasi ini tergolong lambat dibandingkan dengan wilayah-wilayah lain di Nusantara. Lihat juga. Ahmad M. Sewang, Islamisasi Kerajaan Gowa (Abad XVI sampai Abad XVII), (Jakarta: Yayasan Obor Indonesia, 2005), h. 97-103.

15 Penyebutan nama wilayah itu, disebutkan dalam sebutan saat ini sebagai negara modern. lihat 
Sekitar abad ke-15 sampai abad ke-20 merupakan awal masa kolonialisme dan imperialisme, orang-orang Eropa dan Amerika mulai berdatangan ke Asia Tenggara. Usaha dominasi kolonialis menimbulkan perlawanan dari para kerajaan yang telah mematok kekuasaannya lebih dahulu, termasuk kerajaan-kerajaan Islam yang tumbuh subur di wilayah ini sekitar abad tersebut. Semua negara di Asia Tenggara merasakan buruknya kolonialisme, kecuali Thailand. ${ }^{16}$ Oleh sebab itu, menjadi penting untuk menjadikan fase ini sebagai salah satu titik tolak untuk melihat dinamika sejarah Islam di wilayah ini.

Imperium Eropa menyusuri wilayah ini bukan hanya mengejar kuasa, kekayaan alam, namun juga menyebarkan paham hidup, seperti kebudayaan, bahasa, dan agama di wilayah Indonesia yang dikuasai pasukan Belanda; Malaysia, Brunei, dan Singapura oleh pasukan Inggris; Filipina, oleh Spanyol; dan negara-negara di daratan Asia Tenggara, meliputi Vietnam, Cambodia, Laos, dan Myanmar dikuasai oleh Pasukan Perancis. Belakangan kemudian, turut serta Amerika dan Jepang.

\section{Ekspansi Pemerintah Kolonial}

Pada tahun $1511 \mathrm{M}$ rombongan orang-orang Eropa Portugis pertama kali datang ke wilayah Nusantara di wilayah kekuasaan Kesultanan Malaka ${ }^{17}$ di mana tahun itu juga menjadi tahun berdirinya kerajaan Aceh Darussalam, setelah melepaskan diri dari kerajaan Pedie atas kontribusi Sultan Ali Mughiyat Syah yang kemudian didaulat menjadi raja pertama (1514-1528 M). Kerajaan Aceh melancarkan ekspansi, selain motif politik, motif agama juga terlibat penting di dalamnya, misalnya ketika melakukan penyerangan kepada kerajaan Pedie yang berkongsi dengan Portugis. Salah satu penyebab kemunduran kerajaan Aceh karena lemahnya organisasi pemerintahan pasca Sultan Iskandar Muda (1607-1638) yang

\footnotetext{
${ }^{16}$ Thailand adalah salah satu negara di Asia Tenggara yang tidak merasakan kolonialisme secara nyata, walaupun secara tidak langsung Thailand mendapatkan pengaruhnya, misalnya dalam sistem bernegara dan aturan-aturan hukum terpengaruh oleh administrasi pemerintahan ala kolonial, misalnya perubahan dari sistem kerajaan absolut ke sistem monarki konstitutional.

17 Max L. Gross, A Muslim Archipelago : Islam and Politics in Southeast Asia, (Washington: National Defense College, 2007), h. 8.
} 
melemahkan sendi-sendi pemerintahan, termasuk aspek ekonomi, sehingga kerajaan Aceh terdesak dan harus bekerjasama dengan kolonial. ${ }^{18}$

Pada tahun $1565 \mathrm{M}$ rombongan kedua memasuki Filipina, rombongan tersebut adalah orang-orang Spanyol, yang kemudian melakukan ekspansi hingga ke selatan Filipina, di mana Kesultanan Sulu berkuasa. Yang dengan cepat bergerak ke timur dan mengekspansi wilayah Kesultanan Ternate (1574) namun kemudian kekuatan Spanyol melemah setelah meninggalnya Raja Portugal Phillip II. ${ }^{19}$ Penjajahan Spanyol berhasil melancarkan katolikisasi di bagian utara dan tengah kepulauan Filipina, namun gagal di bagian selatan, atas perlawanan dua kesultanan besar, kesultanan Maguindanao dan Kesultanan Sulu. Dalam mempertahankan wilayahnya tercatat, setidaknya terjadi 6 kali periode peperangan antara kesultanan Islam dan Spanyol untuk mempertahankan wilayahnya yaitu:

1. Pada tahun $1565 \mathrm{M}$ yang berakhir ketika berhasil menaklukkan Brunei Darussalam pada $1578 \mathrm{M}$ dan pada $1580 \mathrm{M}$ peperangan berlanjut dan Spanyol berhasil mengalahkan Raja Sulaiman dan Raja Lakadula, ${ }^{20}$ yang menjadi penanda resmi penjajahan Spanyol di Filipina.

2. Pada tahun 1587-1599 M terjadi perang Moro ke-2, kaum Muslim menyerang ke kepulauan yang dikuasai Spanyol, dan berakhir pada tahun $1635 \mathrm{M}$ ketika benteng Zamboanga berhasil didirikan.

3. Ketika Sultan Nasruddin berhasil mempersatukan umat Muslim dalam sebuah perjanjian pada 1645 M. ${ }^{21}$ Pada tahun $1656 \mathrm{M}$ Sultan mengumandangkan seruan Jihad dan berhasil mengusir Spanyol dari wilayah Zamboanga pada $1663 \mathrm{M}$.

18 M. Yahya Harun, Kerajaan Islam Nusantara abad XVI dan XVII, (Yogyakarta: Kurnia Kalam Sejahtera, 1994), h. 11.

${ }^{19}$ Max L. Gross, ,A Muslim Archipelago : Islam and Politics in Southeast Asia, h. 9.

20 Raja Sulaiman adalah pemimpin pemerintahan di Manila dan Raja Lakadula adalah pemimpin Pemerintahan di Tondu.

21 Perjanjian ini berhasil mempersatukan Muslim yang tersebar di wilayah kepulauan, antara lain, Lanao, Zamboanga, Davao, Cotabato, Cagayan de Auro dan Bukitnon. 
4. Pada tahun $1718 \mathrm{M}$ Spanyol menyerang kembali ke wilayah Selatan dan berakhir ketika berhasil menaklukkan Jolo, ibukota kesultanan Sulu.

5. Perang Moro V dimulai pada tahun $1718 \mathrm{M}$

6. Pada tahun $1852 \mathrm{M}$, Perang Moro kembali pecah untuk ke-6 kalinya, dan berakhir dalam sebuah perjanjian pada tahun $1876 \mathrm{M}$.

Peralihan kekuasaan Filipina, yaitu ketika Spanyol kalah perang dari Amerika pada tahun $1898 \mathrm{M}$ dan membuatnya terusir dari wilayah tersebut, Amerika memegang kekuasaan baru. Kekuatan Milisi Islam pada masa itu, berada dalam kondisi tak berdaya untuk melakukan perlawanan. Akhirnya, wilayah Mindanao yang merupakan wilayah kekuasaan Muslim resmi masuk dalam wilayah Filipina melalui perjanjian Paris Treaty.

Di bawah kekuasaan Amerika, suhu perlawanan Muslim Filipina menurun, sebab mereka difasilitasi infrastuktur, diberikan hak sama, dan Amerika berhasil meyakinkan Muslim Filipina bahwa tidak akan ada kristenisasi bagi Muslim. Riak-riak perlawanan kepada Amerika muncul pada tahun $1913 \mathrm{M}$, Brigjen Pershing meneruskan proyek reformasi sosial-ekonomi di selatan Filipina, dan berusaha melucuti senjata Muslim, mereka tidak menerima kebijakan ini, karena mereka butuh senjata untuk melawan perlakuan kaum Kristen Filipina. Akibatnya, terjadi pemberontakan untuk melawan kekuasaan Amerika. Selain itu, terdapat pertentangan administrasi tanah, di mana bagi pemerintah Amerika, kepemilikan diakui dengan adanya bukti kepemilikan, sedangkan Muslim Filipina menganggap tanah yang mereka tempati adalah warisan leluhur mereka. Gelombang transmigrasi yang besar, membuat pulau Luzon over-penduduk, sehingga pemerintah mengeluarkan kebijakan untuk memindahkan penduduk mayoritas Kristen ke wilayah Mindanao yang dikuasai muslim, dan mereka sebut Dar al-Islam untuk mendukung rencana ini, pemerintah Amerika mengeluarkan sederet legislasi tentang tanah demi kepentingan kapitalis. ${ }^{22}$ Walau sempat menjadi tempat persitegangan antara Amerika dan Jepang akibat Perang Dunia II pada tahun 1942 M, wilayah Filipina kemudian mendapatkan

22 Legislasi itu, seperti Land Registration Act No. 496 (1902), Phillippine Commission Act no. 718 (1903), Publik Land Act no. 296 (1903), the Mining Law of 1905, Cadastral Act of 1907. Quino-Recto Colonialization Act no. 4197, 
kemerdekaannya pada tahun 1946 yang telah dijanjikan Amerika sebelumnya. ${ }^{23}$

Pada saat penjajah Belanda datang ke Indonesia pada awal abad ke-17, hampir semua kerajaan adalah kerajaan Islam, dan hanya Bali yang masih kerajaan Hindu. ${ }^{24}$ Sejak terjadinya gelombang konversi besar-besaran pada abad ke-13 $\mathrm{M}$, yang dimulai pada pengislaman raja Aceh, Islam semakin berkembang di wilayah ini, dan menemui momentumnya ketika, Islam dengan baik diterima oleh rajaraja Lokal yang kemudian berislam dan mengislamkan sistem pemerintahan dan rakyatnya. misalnya saja, kerajaan Gowa, yang awalnya bukanlah kerajaan Islam, diperkirakan berdiri pada abad XIV, di mana raja pertama adalah Tomanurung atas kesepakatan Paccallaya dengan Kasuwiyang Salapang. pada pemerintahan Tunipallangga, yaitu raja Gowa ke-X yang berkuasa pada tahun 15121546, banyak pedagang yang datang dari Pahang, Patani, Johor, Campa, Minangkabau, dan Jawa yang kemudian menetap di wilayah ini.

Sekalipun telah terjadi kontak awal dengan Islam pada masa raja Gowa ke-X oleh para pedagang yang datang ke daerah ini dan perantau Makassar yang mengunjungi negeri-negeri lain, namun, secara resmi Islam barulah diterima oleh kerajaan Gowa, ketika I Mangarangi Daeng Manrabia Sultan Alauddin Tomninga ri Gowa, raja Gowa ke-XIV, yang berkuasa pada tahun 1593-1653 M. Sultan Alauddin masuk Islam pada 9 Jumadil Awal 1015/22 September 1603 M.

Islamisasi di kerajaan Gowa dilakukan atas dakwah dari 3 muballigh (Datuk Tallua) dari Koto Tangah, Minangkabau, mereka adalah Datuk ri Bandang, Datuk Patimang, dan Datuk di Tiro. ${ }^{25}$ Kontak kerajaan Gowa dengan bangsa Eropa telah berlangsung

${ }^{23}$ Lebih lanjut, Arif Syibromalisi, "Problematika Integrasi Muslim di Filipina PascaKolonial", dalam Choirul Fuad Yusuf, h. 101-129; Ahmad Suaedy, Dinamika Minoritas Muslim Mencari Jalan Damai, (Jakarta: The Wahid Institute, 2012), h. 45-48.

24 Peter Church, A Short History of Southeast Asia, (Singapore: John Wiley \& Sons (Asia) Pte Ltd, 2006), h. 42.

25 Ahmad M. Sewang, Islamisasi Kerajaan Gowa Abad XVI sampai Abad XVII (Jakarta: Yayasan Obor Indonesia, 2005), 88-90. 
sebelum masa Sultan Alauddin, yaitu dengan Portugis, yang telah datang sebelumnya untuk mencari rempah-rempah. Namun, dominasi dimulai ketika bangsa Eropa lainnya, seperti Belanda berusaha melalukan kontak dagang dengan pemerintah kerajaan Gowa, yaitu Sultan Alauddin pada tahun 1603 M yang berkirim surat kepada raja, untuk diizinkan mendirikan kantor dagang di wilayah kerajaan Gowa, terjadi kerjasama antara Belanda dan kerajaan Gowa, sampai akhirnya, terjadi pertikaian pada tahun $1616 \mathrm{M}$, ketika kapal VOC berlayar ke Makassar.

Petinggi kerajaan Gowa diundang oleh Belanda untuk bertamu ke kapal itu, sesampai di kapal, para petinggi kerajaan dilucuti senjatanya, yang kemudian memantik perlawanan, maka terjadi pertikaian besar dan menimbulkan korban. Setelah itu hubungan kerajaan Gowa dan Belanda mulai tidak akur, ditambah lagi, kebijakan VOC pusat yang memonopoli perdagangan.

Sultan Alauddin juga turut membantu kerajaan-kerajaan sekitarnya untuk membantu keluar dari monopoli perdagangan Belanda, misalnya la mengirimkan pasukan ke Ambon untuk membantu rakyat Ambon melawan Belanda. Melihat ini, pihak Belanda berusaha memblokade perdagangan rempah-rempah ke kerajaan Gowa, namun tidak berhasil. Lalu dilaksanakan perundingan tentang perdagangan bebas, melihat kekuatan kerajaan saat itu, Belanda tidak kuasa menolak, dan akhirnya hasil perundingan itu diterapkan sampai masa raja berikutnya Sultan Malik al-Said (16391653) hubungan Gowa-Belanda berlangsung damai pada masa ini. Namun, tidak masa setelahnya, ketika pemerintahan I Mallombasi Daeng Mattawang Karaeng Bonto Mangape Sultan Hasanuddin Tominanga ri Balla'pangkana (1653-1669).

Kerajaan Gowa dianggap oleh Belanda sebagai satu-satunya penentang hegemoni militer dan penentang politik perdagangan Belanda, namun, karena kekuatan militer Gowa yang kuat, tidak mudah bagi Belanda untuk melakukan penyerangan, melihat itu, Belanda menggunakan strategi divide et impera. Di mana Belanda bekerjasama dengan Arung Palakka (1634-1696), yang merupakan pengerang Bugis dan berada dalam persekutuan Gowa. Pada 1660 terjadi pemberontakan sekitar 10.000 rakyat Bone di bawah pimpinan Arung Palakka, namun berhasil dikuasai oleh Gowa. Pasca kejadian 
itu, Arung Palakka minta perlindungan pada kerajaan Buton dan kemudian pada tahun 1663 M berangkat ke Batavia (Jakarta) dan bergabung dengan VOC. Pada $1666 \mathrm{M}$, Cornelis Speelman dengan prajuritnya, termasuk Arung Palakkad an sekutu bugisnya, tiba di Makassar, dan perang antara kerajaan Gowa dan VOC terjadidisebut perang Makassar-yang berlangsung selama hampir setahun. Akhir dari perang itu dimenangkan oleh VOC dan memaksa kerajaan Gowa di bawah kuasa Sultan Hasanuddin untuk tunduk dan menandatangai Perjanjian Bongaya (Het Bongaais Verdrag) pada 18 November 1667 M. Akibat perjanjian ini, wilayah kekuasaan Gowa semakin berkurang, dan menyebabkan para prajuritnya meninggalkan kerajaan Gowa. Salah satunya adalah Syekh Yusuf al-Makassari bersama pasukan Makassarnya menuju Banten dan membantu Sultan Ageng Tirtayasa melawan Belanda. ${ }^{26}$ ketika dicermati, sejak awal kedatangan Belanda pada awal abad ke-17, mereka telah mendapat perlawanan dari para raja yang telah memeluk Islam pada waktu yang bersamaan.

Kerajaan Patani yang menguasai wilayah Patani (Thailand Selatan) adalah salah satu kerajaan Islam yang pernah berkuasa di wilayah Asia Tenggara. Patani mencapai kejayaannya pada 15841624, di mana wilayah Patani menjadi salah satu pusat niaga yang penting dan merupakan wilayah pertumbuhan kebudayaan Melayu, sehingga disegani oleh bangsa-bangsa lain. ${ }^{27}$

Pada sekitar tahun 1300 an, Singapura seolah terlahir kembali pada masa kolonialisme Inggris pada 1819, ketika Stamford Raffles (perwakilan Hindia Belanda) mengadakan negosiasi dengan Temenggong dan Sultan Hussein (Sultan Johore) untuk menduduki wilayah Pulau tersebut, dan keduanya kekuasaan Inggris dan kesultanan Johore berkuasa hingga 1924. Pada 1963, Singapura bergabung dengan negara Federasi Malaysia, dan kemudian memisahkan diri dan menjadi negara merdeka pada 1965.

\section{Pembaruan dan Munculnya Gerakan-Gerakan Muslim}

${ }^{26}$ Selain berperan melawan Belanda, tujuan utama Syekh Yusuf al-Makasari ke Banten adalah untuk menuntut IImu. M.C. Ricklefs, a History of Modern Indonesia Since c. 1200 (edisi ke-3: London: Palgrave, 2001), 102.

27 Choirul Fuad Yusuf dkk,Dinamika Islam Filipina, Burma, dan Thailand (Jakarta: Badan Litbang dan Diklat Kementrian Agama RI, 2013) h. 310. 
Pada abad ke-17, Isu pembaruan mendapatkan momentumnya, ketika jaringan keilmuan Islam terjalin dari Mekkah dan Madinah ke seluruh Dunia, termasuk wilayah Nusantara. Semangat beribadah haji telah mendorong Ulama dan penuntut IImu untuk mendatangi dan bermukim di kedua kota ini. dari kedua kota ini terjadi transmisi gagasan pembaruan yang menyebar ke seluruh dunia melalui peran Ulama. Di wilayah Nusantara, terdapat banyak ulama-ulama yang menuntut IImu ke Mekkah dan Madinah, di antaranya Nur al-Din alRaniry (w.1658), Abd al-Rauf al-Sinkili (1615-93) dan Syekh Yusuf alMakassari (1627-99). ${ }^{28}$ Salah satu pembahasan penting dalam masa kolonialisme dan imperialisme Eropa dan Amerika di Asia Tenggara adalah munculnya perlawanan dari kaum pribumi (indegeneous) yang terbentuk dalam gerakan-gerakan dengan beragam ideologi untuk mempertahankan wilayah tanah air dan kebudayaannya. Islam sebagai keyakinan yang telah hidup dalam masyarakat, berabad-abad sebelum Kolonial dan imperialis hadir ke wilayah ini, menjadi satu perekat penting persatuan masyarakat dalam gerakan itu, bahkan Islam telah dijadikan sebagai ideologi perjuangan untuk mempertahankan tanah air dan kebudayaannya. Namun, perbedaan pandangan satu sama lain dalam masyarakat Muslim juga tak bisa terhindarkan, sehingga dalam masyarakat Muslim sendiri muncul beberapa kelompok yang memiliki visi sama mempertahankan tanah air walau dengan gerak dan metode yang berbeda.

Perjuangan melawan kolonialisme dan imperialisme yang telah dimulai pada masa kerajaan, dilanjutkan oleh masyarakat generasi selelahnya dengan berhimpun dalam kelompok-kelompok perjuangan. Di Indonesia muncul Sarekat Dagang Islam (1909), Perserikatan Ulama (1911), Muhammadiyah (1912), Persatuan Islam (1920). Nahdhatul Ulama (1926) adalah gerakan-gerakan yang muncul sebagai reaksi ketertinggalan masyarakat Indonesia akibat kolonialisme yang berkepanjangan dan kebutuhan genting akan perubahan dan reformasi. ${ }^{29}$

Lembaga Islam lainnya adalah lembaga pendidikan, pengadilan Syariah dan lembaga yang mengurusi urusan perkawinan. Problem

${ }^{28}$ Azyumardi Azra, Jaringan Ulama Timur Tengah dan Kepulauan Nusantara Abad XVII \& XVIII, (Jakarta: Kencana, 2013), h. xxiv-xxv,

${ }^{29}$ Kuntowijoyo, Paradigma Islam : Interpretasi untuk Aksi, h. 79. 
Muslim ekstremis dan radikalisme Islam juga di rasakan di Singapura, untuk menangkal itu, MUIS sejak tahun $2002 \mathrm{M}$, pertemuan dengan ketua-ketua lembaga keagamaan dilakukan untuk membahasa ini, dan pada tahun 2005 M, MUIS memberlakukan sistem "Asatizah Recognition Scheme" untuk menyaring pengajar agama Islam, dan pada tahun $2006 \mathrm{M}$ melalui lembaga "Centre for Contemporary Islamic Studies" diadakan untuk mengaktifkan kembali program dialog lintas Iman (inter-faith diaologue). ${ }^{30}$

Berbeda dari negara-negara tetangganya, masyarakat Muslim Patani, bukan melawan penjajah namun, terlibat konflik arogansi kekuasaan dengan kerajaan lokal kerajaan Siam, muncul reaksi besar ketika Patani akan diintegrasikan dengan Thailand (1902-1932), pada tahun 1902 M raja-raja Patani dilucuti kekuasaannya dan wilayah tersebut diintegrasikan dalam satu wilayah kekuasaan politik dan administrasi Kerajaan Siam, momentum itu adalah ketika kerajaan Siam melaksanakan undang-undang Thesaphiban, yang berdampak pada penghapusan kesultanan Melayu. Pada tahun 1909 M, ketika Perjanjian Bangkok dilaksanakan, Inggris pun mengakui wilayah Patani sebagai jajahan kerajaan Siam. Sejak saat itu, muncul berbagai gejolak dari masyarakat Muslim Selatan Thailand, setidaknya terjadi 5 kali pemberontakan Muslim di selatan Thailandpada 1903 dipimpin Abdul Kadir, 19010 dipimpin Ulama To'Tae, 1911 dipimpin oleh Haji Bula, 1915 dipimpin oleh To' Janggut, dan 1922 dengan dukungan yang lebih besar dipimpin oleh Abdul Kadir. Pemberontakan itu membawa dampak baik, pada 1932 pemerintah kerajaan Thailand memberikan sedikit kelonggaran pada Muslim Patani, di mana Patani memperoleh Otonomi pada tingkat tertentu dan secara resmi karakteristik kewilayahannya diakui. ${ }^{31}$

Pada wilayah Thailand selatan yang berbatasan dengan Malaysia dan terikat dalam rumpun Malaysia bergejolak gerakan untuk memisahkan wilayah ini dari wilayah Administrasi. Sebagai penganut agama terbesar kedua setelah Budha, gerakan separatis

\footnotetext{
${ }^{30}$ Hussin Muthalib, Islam in Southeast Asia(Singapore: Institute of Southeast Asian Studies, 2008), h. 50-53.

31 Syaukani, "Sejarah Islam di Pattani Thailad" dalam Choirul Fuad Yusuf, Dinamika Islam Asia tenggara. h, 310-313
} 
Muslim Thailand cukup memberi pengaruh dalam stabilitas politik di kerajaan Thailand. Pada era ini muncul gerakan-gerakan seperti Pattani United Liberation Front (PULO), Barisan Revolusi Nasional, dan beberapa organisasi pemuda, masyarakat, dan volunteer nonpemerintahan yang menjalar di Thailand.

\section{Pasca-Kolonialisme}

Masa pasca-kolonialisme dimulai dari kemerdekaan negara-negara di Asia Tenggara, dari tahun 1940an sampai sekarang. ${ }^{32}$ Sebagaimana yang disebutkan sebelumnya, bahwa para Muslim memainkan peran besar dalam politik dari masa kerajaan, masa kolonialisme, dan puncaknya pada masa pasca-kolonialisme, ketika indepensi politik terbebas dari intervensi kuasa kolonial yang berlangsung selama lebih dari tiga abad. Kolonialisme yang berlangsung dari abad keenam belas hingga awal abad ke-20 ini membawa dampak signifikan pada kesemua wilayah di Asia Tenggara. Nation-state dan sekularisasi adalah salah satu dampak kolonialisme dalam tradisi pemerintahan, secara sederhana bisa dinyatakan bahwa hanya Brunei Darussalam yang bisa bertahan atas kebijaksanaan Inggris untuk menerapkan Sistem Pemerintahan Islam melalui sistem monarki absolut, di mana Sultan Hassanah Bolkiah ke-29 bertindak sebagai kepala Negara. Pada bagian ini, pembahasan terfokus pada dinamika Islam yang terjadi pasca-kemerdekaan negara-negara di Asia Tenggara, yang berlangsung mulai tahun 1940an sampai awal tahun 2000an, seperti dinamika sosial, politik, dan hukum yang terjadi pada masyarakat Muslim di Asia Tenggara.

\section{Negara Bangsa dan Sekularisasi di Asia Tenggara}

Isu sekularisasi berkembang di Asia Tenggara, yang ditumbuhsuburkan oleh kontestasi isu penerapan sistem negara-bangsa (nation state) dan negara Islam. perdebatan terjadi di kalangan para modernis dan tradisionalis. Perdebatan itu diwarnai dengan perdebatan panjang antara partai nasionalis dan Islamis (agama),

32 Filipina adalah negara yang meraih kemerdekaan sebanyak dua kali. Namun, kita akan mulai pembahasan pada pasca-kemerdekaan kedua pada tahun 1947. 
yang menginginkan ideologinya yang digunakan sebagai basis negara.

Lutfie Asy-Syaukani menggambarkan bahwa, setidaknya telah terjadi perkembangan pemikiran politik Islam oleh para pemikir Muslim sejak era-kemerdekaan sampai era-sekarang. Kemudian dibagi ke dalam 3 tahap, dimulai pada fase awal pembentukan negara ini.

Pertama, pemikiran "Negara Demokrasi Islam" diusung oleh Mohammad Natsir (1908-93), yang juga menjadi ketua partai Masyumi yang berdiri pada posisi Oposisi pada pemerintahan Soekarno. la berpandangan bahwa negara berdasarkan Islam bukanlah teokrasi, melainkan Negara Demokrasi. Tokoh lainnya adalah Zainal Abidin Ahmad (1911-83), Sjafruddin Prawiranegara (1911-89) dan lainnya.

Kedua, pemikiran pemikir Muslim tentang "Negara Demokrasi Agama", yang muncul pada era-1970an. Masa itu adalah masa peralihan tata politik dari orde lama ke orde baru, pada masa ini terjadi pula transisi dari Muslim santri lama ke baru. Di mana generasi muda muslim mulai muncul dan memberikan suasana politik baru. Mereka kebanyakan sekolah di Barat, dan memiliki pengetahuan ilmuilmu sekuler yang sama baiknya dengan agama. Mereka menjadi akomodatif dan meninggalkan pertentangan ideologis yang terjadi di antara pendahulunya. Tokohnya misalnya, M. Sjafaat Mintaredja (1921), M. Mukti Ali (1923-2004). Pendukung model ini kebanyakan berasal dari Muhammadiyah, seperti M. Amien Rais, M. Syafii Maarif, Kuntowijoyo dan M. Dawam Rahardjo.

Ketiga, pemikiran tentang "Negara Demokrasi Liberal" pemikiran bertumpu pada liberalisasi politik. Cikal bakal munculnya terlihat pasca-kejatuhan rezim orde baru, dan dimotori oleh generasi muda, untuk menuntut kebebasan dalam berbagai hal. ${ }^{33}$ Liberalisme di Indonesia tidak muncul secara tiba-tiba, namun telah ada pada masa 1970an, di mana Nurcholish Majid dan Djohan Effendi tampil sebagai juru bicaranya. Nurcholis Majid ingin membawa keluar Umat Islam dari kejumudan berfikir, untuk bersikap terbuka dalam

${ }^{33}$ Lihat juga Luthfi Assyaukanie, Ideologi Islam dan Utopia : Tiga Model Negara Demokrasi di Indonesia, (Jakarta: Freedom Institute, 2011), h. 18-23. 
mengembangkan ajaran-ajaran Islam, sehingga mencapai integrasi umat. 34

Era-Soeharto, yang cenderung menaruh curiga pada kelompok Islamis untuk mewujudkan Negara Islam. kecurigaan ini sangat wajar, melihat perjuangan para pendukung negara Islam pada era orde lama, bahkan menimbulkan pergolakan berbau separatisme di beberapa wilayah NKRI, misalnya gerakan Darul Islam-Tentara Islam Indonesia (DI-TII) yang dipimpin oleh Kahar Muzakkar di Sulawesi, Angkatan umat Islam di Kebumen. Dan berbagai ketegangan yang muncul antara kelompok-kelompok Islam dan Pemerintah. ${ }^{35}$

Di Malaysia, kontestasi kelompok Nasionalis dan Islamis telah berlangsung sejak Inggris memberikan kemerdekaan pada tahun 1957 M, di mana Tunku Abdul Rahman (1957-1970) menjadi perdana menteri pertama, perdebatan di parlemen antara dua kelompok berlangsung, di mana PM Abdul Rahman mengeluarkan statemen bahwa Malaysia terdiri dari masyarakat multi-etnik dan multi-agama, yang tidak mungkin memaksakan non-Muslim mengikuti aturan hidup Muslim. ${ }^{36}$ Perdebatan terjadi oleh dua tokoh Muslim yang mewakili partai Islam di Malaysia, yaitu Unity Malay National Front (UMNO) dan Partai Islam se-Malaysia (PAS). Isu penegakan negara Islam di Malaysia tumbuh subur di bawah pengawalan Partai Islam seMalaysia (PAS) yang selalu duduk dalam jajaran oposisi, melawan UMNO yang dianggap sebagai partai sekuler. Momentum perkembangan Islam dan Islamisasi semakin gencar ketika Dr. Mahathir Mohammad menjabat Perdana Menteri pada tahun $1981 \mathrm{M}$, yang kemudian melalui pemerintahannya mendeklarasikan Islamisasi Perangkat Pemerintahan pada tahun $1984 \mathrm{M}$. Melalui pemerintahan Mahathir lembaga-lembaga Islam dikembangkan dan hubungan luar

\footnotetext{
${ }^{34}$ Nurcholish Majid, Islam Kemodernan dan Keindonesian, (Jakarta: Mizan, 2008), h. 225.

${ }^{35}$ Kuntowijoyo, Paradigma Islam : Interpretasi Untuk Aksi, (Jakarta: Mizan, 2008), h. 170-226.

36 Tunku Abdul Rahman adalah tokoh partai Unity Malays National Party (UMNO) yang berideologi Nasionalis, yang menentang statemen Dato' Haji Yahya bin Haji Wan Mohamed pada sidang parlemen yang ingin mendirikan negara Islam Malaysia. Lihat juga. Peter G. Riddell, "Islamization, Civil Society, And Religious Minorities in Malaysia", dalam K.S Nathan and Mohammad Hashim Kamali Islam in Southeast Asia, (Singapore: Institute of Southeast Asian Studies. 2006), h. 163164.
} 
negeri sesama negara Muslim diperkuat. ${ }^{37}$ Pemerintahan Mahathir mulai terguncang pada 1990an ketika terjadi ketegangan dengan wakilnya, Anwar Ibrahim, yang kemudian berujung pada pemberhentian Anwar Ibrahim. Pemecatan ini, menimbulkan reaksi oleh para pendukung Anwar yang menjadi gerakan Reformasi untuk melawan Mahathir.

Suasana ini, membawa PAS dan DAP sebagai oposisi bergabung dalam aliansi "barisan alternatif" bersama Partai Keadilan-dipimpin Anwar Ibrahim-. 'barisan alternatif' yang menyatukan PAS dan Anwar menyebabkan berkurangnya suara UMNO pada pemilu tahun $1999 \mathrm{M}$, namun kemudian terselamatkan oleh dukungan dari non-malayu. Suasana ini, menempatkan posisi dilematis bagi UMNO, yang harus mengakomodir partai pendukung dari etnik non-melayu—khususnya china—, pada sisi lain, harus memperlihatkan keberpihakannya pada Islam Melayu, untuk melawan PAS yang terus konsisten pada perjuangan membentuk "negara Islam". pada tahun 2003 M, Mahathir mengundurkan diri, dan digantikan oleh wakilnya, Abdullah Ahmad Badawi, yang meneruskan pemerintahan pro Islam Mahathir. Pada masa pemerintahan Bawadwi, ia mencetuskan proyek "Islam Hadhari", sebuah konsep pemerintahan yang ingin mempromosikan Islam yang modern, progressif, dan toleran kepada sesama, lebih khusus pada nonMuslim. kehadiran Islam Hadhari untuk menepis perjuangan Muslim Ekstremis di Malaysia pasca peristiwa WTC di Amerika. Namun kemudian menjadi rayuan dan slogan kampanye pada tahun $2004 \mathrm{M}$, yang dinilai sukses untuk mengembalikan citra UMNO sebagai partai penguasa di Malaysia dan memenangkan Ahmad Badawi sebagai perdana menteri. ${ }^{38}$

Brunei Darussalam, adalah negara yang secara suhu politik Islam stabil di Asia Tenggara, setelah menolak ajakan bergabung dengan Malaysia dan memperoleh kemerdekaannya dari Inggris pada 1984. Sistem Politik Kerajaan berlaku kembali dalam Negara Brunei

\footnotetext{
37 Pada masa ini, pengajaran agama dijadikan materi utama di sekolah, program Islami di radio dan televisi diperbanyak, dan didirikan lembaga-lembaga, seperti International Islamic University of Malaya (IIUM); dan lembaga bank dan keuangan Syariah, lihat Hussin Muthalib, Islam in southeast Asia, h. 27.

${ }^{38}$ Hussin Muthalib, Islamic in Southeast Asia, h, 32-33.
} 
Darussalam, di mana Keluarga Kerajaan-Sultan Hassanah Bolkiah-yang memegang tampuk kepemimpinan Negara. Walau sempat terjadi ketegangan politik antara modernis dan tradisionalis (pihak kerajaan) terkait dengan wacana penolakan atas sistem monarki kerajaan yang terjadi di negara tersebut, namun, kemudian stabil kembali atas kekuasaan kerajaan dan bantuan Inggris. ${ }^{39}$

Thailand sebagaimana dijelaskan sebelumnya-karena posisi yang minor, dan tersudutkan pasca dilucutinya kekuasaan kerajaan Patani pada 1902 oleh kerajaan Siam (Thailand), muslim Thailand bersikap separatis dan memunculkan pemberontakan-pemberontakan antara tahun 1902-1932. Pemberontakan itu berakhir, ketika pemerintah kerajaan Thailand meninjau ulang perjanjian yang menghapuskan kekuasaan kerajaan Pattani, dan memberikan otonomi dalam batas tertentu, untuk masyarakat Muslim di selatan Thailand dan mengakui akan karakteristik-karakteristik khusus yang dimiliki masyarakat di daerah ini. sejarah gerakan Muslim di Thailand setelah tahun 1930an, tak bisa dilepaskan dari gerakan pemuda. Pada 1960an, The Thai Muslim Student Association (TMSA) memegang peranan penting dalam menumbuh kembangkan kesadaran politik kalangan muda, yang pada 1973 berhasil menumbangkan rezim diktator Thanom Kittikachorn. TMSA dinggap bukan sekedar organisasi pemuda tapi merupakan "civil society", dalam melakukan pressure politik, TMSA menghindari konflik dengan pemerintah, namun, bersikap lebih koperatif. ${ }^{40}$ Era 1970 an adalah erareformasi dalam kubu masyarakat Muslim di Thailand, pada masa ini muncul gebrakan-gebrakan yang dilakukan Muslim Thailandsebagai masyarakat minor--, misalnya gerakan Hijab, yang dimotori oleh perempuan-perempuan Muslimah Thailand yang memprotes kebijakan kampus yang melarang Muslimah menggunakan Hijab

39 Selain menolak monarki kerajaan, juga menolak rencana peleburan negara ini ke melaysia pada 1963, yang mengakibatkan terjadinya pemberontakan dari kaum modernis yang dipimpin oleh Yassin Affandi, dan dari partai oposisi Partai Rakyat Brunei yang dipimpin oleh A.M. Azhari memenangkan pemilu 1962 yang berusaha menggugurkan rencana itu. Hussin Muthalib, Islam in Southeast Asia, (Singapore: Institute o Southeast Asian Studies, 2008), h. 41-42

40 Preeda Prapertchob, "Islam and Civil Society in Thailand". Dalam Nakamura Mitsuo, Sharon Siddique, dan Omar Farouk Bajunid, Islam and Civil Society in Southeast Asia (Singapore: Institute of Southeast Asian Studies, 2001), h. 106110. 
dalam kampus pada 1988. Terdapat 10.000 orang yang berkumpul di Mesjid Pusat Yala untuk melakukan protes, dan tuntutan mereka dipenuhi. Islam di Thailand semakin mendapat tempat baik di ruang publik bahkan terlibat politik dan memegang jabatan-jabatan penting di pemerintahan. Misalnya Wan Muhammad Noor Matha yang menjabat sebagai president of National Assembly Thailand; Dr. Surin Pitsuwan yang menjabat sebagai menteri luar negeri dan sekarang menjabat sebagai Sekjend ASEAN; Areepen Uttarasin menjabat menteri pendidikan.

Hampir sama dengan pengalaman Muslim Thailand, Muslim di selatan Filipina juga terlibat dalam pemberontakan dan separatisme untuk menuntut kebebasan dan pendirian negara Islam. perbedaannya terletak pada reaksi pemerintah—kolonial Spanyoldalam merespons tuntutan Muslim Filipina dan adanya kontestasi kepentingan Islam dan Kristen. Moro National Liberation Front (MNLF) dan Moro Islamic Liberation Front (MILF) adalah dua kelompok politik sekaligus militer yang berjuang untuk terlaksananya sistem politik Islam di Filipina-khususnya Filipina selatan. Filipina pasca-kolonialisme, pemerintah membentuk Komisi Integrasi Nasional (1957) yang bertujuan untuk menyamakan standar hidup warga Kristen dan Muslim, namun Muslim menolak ini, karena khawatir akan melunturkan kebudayaan mereka. ${ }^{41}$ Jika diurai ke belakang, tuntutan separatisme telah dimulai sejak era kesultanan yang terus dilanjutkan hingga hari ini.

Kelompok minoritas muslim Myanmar (Burma) terbagi dalam 3 kelompok, yaitu:

1. Muslim Zerbadee, yaitu Muslim Burma keturunan dari Timur Tengah dan Asia selatan, yang telah menetap lama, dan telah menikah dengan warga setempat.

2. Muslim India, yang terbentuk akibat kolonialisasi Inggris.

3. Muslim Rohingya (Rakhine), yang menempati wilayah Arakan yang berbatasan dengan Bangladehs, kelompok ini adalah kelompok terbanyak di Myanmar.

41 Choirul Fuad Yusuf, dkk, Dinamika Islam : Filipinan, Burma, dan Thailand, (Jakarta: Puslitbang Lektur dan Khazanah Keagamaan Badan Litbang dan Diklat Kementrian Agama RI, 2013), h. 63. 
Selepas kemerdekaan pada 1948, Perdana Menteri U Nu mengakomodasi kepentingan semua agama, termasuk Islam, sehingga Muslim mendapatkan jabatan pemerintahan dan memiliki kebebasan dalam dunia perdagangan. Kedamaian berakhir, ketika PM U Nu terbunuh, dan kekuasaan diambil alih oleh kalangan Militer, $\mathrm{Ne}$ Win pada tahun $1962 \mathrm{M}$. Rohingya yang sejak lama mendapat sentimen dari kalangan militer, tersudutkan, dan mengalami kekerasan, khusunya Muslim di Rohingya. Sentimen berlebihan dari militer telah berlangsung sejak tahun 1930an, ketika militer membantai Muslim di Yangon dan Mandanay. Pada tahun 1977 M ketika pemerintah melaksanakan operasi "naga min" yang mengklasifikasikan penduduk Myanmar dalam dua kategori, Burma dan Asing, muslim semakin termarginalkan, masjid dibakar, wilayah mereka diambil alih, wanita dipaksa menikah dengan tentara Budha, bahkan sebagian diperkosa.

Pada tahun $1964 \mathrm{M}$, umat Muslim di Myanmar dilarang menunaikan haji, namun pada tahun $1980 \mathrm{M}$ aturan tersebut dicabut kembali. Secara politik, sebelum tahun 1962 M Rohingya dikenal sebagai etnik asli Burma, sehingga mereka mendapatkan akses politik dan akses ke ruang publik seperti menjadi pegawai di kantor pemerintah, namun, setelah rezim militer berkuasa, terlebih ketika undang-undang kewarganegaraan keluar pada tahun $1982 \mathrm{M}$, mereka dianggap sebagai bukan penduduk asli, sehingga akses politik dan ruang publiknya dilucuti oleh pemerintah. Sederetan stigma yang berujung pada marginalisasi kelompok Muslim Myanmar, adalah pemantik reaksi masyarakat untuk melawan dan bisa keluar dari suasana yang tidak baik itu, melalui Arakan National Union Organization (ANUO), Muslim Myanmar menuntut pendirian negara otonom, namun ditolak. Lalu akhirnya Muslim Rohingya bergabung di bawah pemberontakan gerakan Mujahidin yang dipimpin Jafar Hussain yang terbentuk pada 1947.

Pada tahun $1950 \mathrm{M}$, Jafar Hussein dibunuh, dan digantikan oleh Cassim, selepas itu, genderang Jihad ditabuh, lawannya bukan pemerintah, namun penduduk Budha yang menduduki wilayah Arakan, pemberontakan Mujahidin melebar dan menguasai wilayah Arakan. Krisis politik di Burma pada masa itu, memperkuat posisi Mujahidin, tuntutan mereka sederhana, agar diberikan daerah khusus 
bagi Umat Islam di bagian perbatasan utara Myanmar. Pada tahun 1951-1954 M, militer Burma di fokuskan di wilayah arakan untuk menumpas Mujahidin, operasi ini dikenal "Operation Mansoon" utnuk memecah persatuan pemberontak, pada operasi ini, Cassim diitangkap dan dikirim ke Pakistan. Semangat untuk menjadikan Arakan sebagai wilayah otonom tidak berhenti sampai di situ, pasca operasi itu, isu State of Arakan semakin mengemuka, yang kemudian dituangkan dalam perjuangan politik memenangkan $U \mathrm{Nu}$ yang menjanjikan negara otonom bagi arakan.

Setelah mencapai kemenangan, $U \mathrm{Nu}$ menepati janjinya, dengan membentuk Negara Mon dan Arakan, namun kelompok Mujahidin tetap tidak puas, dan ingin wilayah otonomi secara Agama (Islam). gerakan-gerakan perlawanan bermunculan, seperti Rohingya Independence Force (RIF) pada tahun 1963 M yang dibentuk Muhammad Jafar Habib, adalah pembaruan dari gerakan Mujahidin Jafar Hussain, yang kemudian berubah nama pada tahun 1969 M menjadi Rohingya Independence Army (AIR), kemudian berubah nama Rohingya Patriotic Front (RPF) pada tahun 1973 M sebagai organisasi yang lebih sistematis; National Liberation Party dipimpin oleh Zafar Sani, yang berkoalisi dengan Communist Party of Arakan (CPA), dan Arakan National Liberation Party (ANLP); Rohingya Solidarity Organization (RSO) pada 1982; Arakan Rohingya Islamic Front (ARIF) pada 1986. ${ }^{42}$

Pengalaman marginalisasi dan tersudutkan juga terjadi pada masyarakat Muslim di Cambodia (Kampuche), Vietnam, dan Laos. Mayoritas Muslim di tiga negara ini berasal dari etnik Melayu, Cham, Lao, dan beberapa bangsa Imigran Tamil, Bangladesh dan lainnya. Ketiga negara ini terletak di daratan (mainland) Asia Tenggara dan saling berdekatan, sulit untuk memisahkan pengalaman beragama

42 Tentang dinamika Islam di Myanmar, selanjutnya bisa dibaca lebih detail dalam Clive J. Cristie, Modern of History Southeast Asia : Decolonization, Nationalism, and Separatism, (London: Tauros Academic Studies an Imprint of I.B Tauris Publisher, 1996), h. 168; Riza Sihbudi (ed), Problematika Minoritas Muslim di Asia Tenggara, (Jakarta: Puslitbang Politik dan Kewilayahan, LIPI, 2000), h. 154-158; Ali Fahrudin, "Perkembangan Islam di Burma Pasca Kemerdekaan : Menelisik Kaum Minoritas Muslim Rohingya" dalam Dinamika Islam di Asia Tenggara, h. 239-294. 
ketiganya, sebab memiliki keterjalinan satu sama lain. Terlebih pascakeruntuhan kerajaan Champa pada $1693,{ }^{43}$ penduduk kerajaan yang mayoritas Muslim meninggalkan tanah Airnya, dan berdiaspora ke Cambodia, Laos, Malaysia, dan Indonesia untuk mencari perlindungan. Dalam persebarannya, misalnya di Malaka, Sumatra dan Jawa mereka berasimilasi dengan budaya Islam Melayu. Berbeda dengan mereka yang menuju mayoritas ke bagian Cambodia ataukah bertahan di Vietnam, mereka memiliki perbedaan dalam budaya berislam. ${ }^{44}$ Pengungsi Cham dari Vietnam, mayoritas menuju Cambodia, mereka diterima dengan baik, dan bersosialisasi dengan masyarakat setempat. Namun, ketika rezim

Pada tahun 1945 M, Vietnam mendapatkan kemerdekaannya dan mendeklarasikan diri menjadi Republik Sosialis Vietnam dengan ideologi komunis sebagai ideologi Negara. Namun, walaupun berideologi Komunis, Vietnam tetap mengatur dan membuat kebijakan bagi orang-orang beragama termasuk Islam dan yang tidak beragama.

\section{Distingsi Islam di Asia Tenggara}

Masuknya Islam di Nusantara disambut oleh peradaban, kebudayaan, dan agama yang telah hidup selama berabad-abad lalu. Bahkan Noerhadi menduga telah hidup agama dalam masyarakat prasriwijaya, dengan mengamati kedewasaan masyarakat Nusantara dalam menerima suatu ajaran baru setelahnya, seperti Hindu, Budha, dan Islam. Pertemuan 2 arus kebudayaan berimplikasi pada lahirnya suatu ciri khas kebudayaan baru. Islam dalam sejarah perjumpaannya dengan kebudayaan masyarakat, Azyumardi Azra mengklasifikasikannya ke dalam 8 kelompok yang dilihat dari tradisi, budaya, dan cara hidupnya, kedelapan itu, Arab, Persia, Turki, Anak Benua India, Nusantara (Asia Tenggara), Afrika-Hitam, Shino-Islam, Barat-Eropa. Ke-8 kebudayaan ini memiliki ciri masing-masing. Asia Tenggara adalah salah satu dari kedelapan kelompok tersebut, yang

43 Michael G. Cotter, "Toward a Social History of The Vietnamese Southward Movement" dalam K.G Tregonning (ed), Journal of Southeast Asian History, vol. 9 , 1968 (Amsterdam: Swet and Zeitlinger, 1997), 18.

${ }^{44}$ Raymond Scupin, "Historical, Ethnographic, and Contemporary Political Analyses of the Muslims of Kampuchea and Vietnam", h. 303. 
masyarakat Muslimnya memiliki perbedaan mencolok dibandingkan dengan masyarakat Muslim di wilayah lain. Masyarakat Muslim di wilayah ini terkenal sebagai Muslim yang toleran, akomodatif, dan cair. Adapun ciri-ciri perbedaan tersebut sebagai berikut:

1. Toleran dan Akomodatif merupakan salah satu kebiasaan masyarakat Muslim di wilayah ini, yang terpengaruh dari budaya komunal, gotong-royong, dan kerjasama yang telah hidup dalam kebudayaan masyarakat.

2. Suka berkumpul adalah ciri khas masyarakat wilayah ini, sehingga pesta-pesta atau kegiatan-kegiatan sering dilakukan untuk menjadi wadah berkumpul, segala hal diperingati dengan berkumpul, misalnya peringatan siklus kehidupan, seperti acara kelahiran, sunatan, perkawinan, sampai kematian.

Muslim Filipina dari suku Tausug di kepulauan Jolo melaksanakan upacara Pagbuhat (bulan ketujuh kehamilan), masa anak-anak, perkawinan, dan kematian. Di Malaysia dan Thailand Selatan ada praktek-praktek Sufi yang dilakukan secara berjamaah dalam bentuk $d z i k r .{ }^{45}$ Anthony $\mathrm{H}$. Johns, dikutip dari Nurcholis majid menyebut bahwa salah satu kekuatan Islamisasi di Asia Tenggara pada abad ke-13 adalah keakuran dalam kelompok-kelompok dagang dan mitra dagang mereka. Lebih jauh, Nurcholis Majid mengemukakan bahwa kekuatan terbesar yang dimiliki bangsa ini adalah ajaran-ajaran Islam seperti musyawarah, adil, adab, hikmah dituangkan dalam konsep sosial dan politik melalui wajah Pancasila, sehingga faktor fundamental dan dinamis dari etika sosial dalam Islam, yaitu egalitarianisme menemukan jalannya untuk diaplikasikan. ${ }^{46}$ Kedua, Islam yang Cair. Sebagai wilayah yang sebagian besarnya kepulauan, karakter Muslim di wilayah ini rupanya terpengaruh dengan suasana geografisnya.

Azyumardi Azra dalam perkuliahan mengemukakannya dengan contoh bagaimana karya-karya tulisan para ulama, seperti Abd alRauf al-Singkili menyebar dengan cepat ke daerah-daerah seperti Mindanao di Filipina selatan, kesultanan Buton di tenggara Sulawesi, dan ke tempat-tempat lain di Nusantara. Watak cair itu, memberikan

\footnotetext{
45 Kuntowijoyo, h. 80-81

${ }^{46}$ Nurcholish Madjid, h. 46-49.
} 
ciri tersendiri bagi masyarakat di wilayah ini, mudah bergaul secara lintas kebudayaan,, dan bersikap terbuka nan inklusif pada setiap perbedaan yang dihadapi.

\section{KESIMPULAN}

Masuknya Islam ke Asia Tenggara menimbulkan perbedaan pendapat di antara para sejarawan. Perbedaan tersebut fokus pada isu tentang asal usul Islam di Asia Tenggara. Perdebatan tentang awal mula hadirnya Islam di wilayah ini, setidaknya memunculkan beberapa teori yaitu: islam berasal dari India, Islam berasal dari Arab dan Islam berasal dari Persia. Teori-teori tersebut muncul dengan bukti-bukti yang mendukung.

Penyebaran Islam di Asia Tenggara melalui cara damai tanpa adanya kekerasan. Cara tersebut melalui proses islamisasi yang secara perlahan mengislamkan penduduk Asia Tenggara. Sehingga Islam diterima dengan baik di Asia Tenggara. Masuknya Islam memberikan pengaruh-pengaruh yang positif, baik di bidang ekonomi, budaya, pendidikan dan lainnya. Pengaruh-pengaruh Islam di Asia Tenggara tidak lepas dari peranan kerajaan Islam yang ikut memperluas ajaran Islam. Seperti halnya, kerajaan Samudera Pasai, Sriwijaya, dan lainnya.

Perkembangan Islam di Asia Tenggara pada setiap NegaraNegara Asia Tenggara berbeda-beda, hal ini disebabkan karena perbedaan adat istiadat, ekonomi dan etnik di masing-masing Negara.

\section{REFRENSI}

Assyaukanie, Luthfi. (2011). Ideologi Islam dan Utopia : Tiga Model Negara Demokrasi, Jakarta: Freedom Institute.

Azra, Azyumardi. (1999). Renaisans Islam Asia Tenggara. Bandung: Remaja Rosdakarya.

Azra, Azyumardi. (2013). Jaringan Ulama : Timur Tengah dan Kepualauan Nusantara Abad XVII \& XVIII. Jakarta: Kencana.

Choirul Fuad Yusuf, dkk. (2013). Dinamika Islam : Filipinan, Burma, dan Thailand. Jakarta: Puslitbang Lektur dan Khazanah Keagamaan Badan Litbang dan Diklat Kementrian Agama RI.

Church, Peter (ed). (2006). A Short History of Southeast Asia. Singapore: John Wiley and Son (Asia) Pte Ltd. 
Cotter, Michael G.. (1997). "Toward a Social History of The Vietnamese Southward Movement" dalam K.G Tregonning (ed), Journal of Southeast Asian History, vol. 9, 1968 (Amsterdam: Swet and Zeitlinger.

Cristie, Clive J.. (1996). Modern of History Southeast Asia : Decolonization, Nationalism, and Separatism. London: Tauros Academic Studies an Imprint of I.B Tauris Publisher.

Fealy, Greg and Virginia Hooker (ed). (2006). Voices of Islam in Southeast Asia. Singapore: Institute of Southeast Asian Studies.

Gibson, Thomas. (2007). Islamic Narrative and Authority in Southeast Asia : from the $16^{\text {th }}$ to the $21^{\text {st }}$ Century. United States: Palgrave Macmillan.

Gross, L. Gross.. (2007). A Muslim Archipelago : Islam and Politics in Southeast Asia. Washington: National Defence Intelligence College.

Kuntowijoyo. (2008). Paradigma Islam : Interpretasi Untuk Aksi. Jakarta: Mizan.

Madjid, Nurcholish. (2008). Islam Kemodernan dan Keindonesian. Jakarta: Mizan.

Mitsuo, Nakamura, Sharon Siddique and Omar Farouk Bajunid. (2001). Islam and Civil Society In Souteast Asia. Singapore: Institute of Southeast Asian Studies.

Muthalib, Hussin. (2008). Islam in Southeast Asia. Singapore: Institute of Southeast Asian Studies.

Nathan, K.S. and Mohammad Hashim Kamali. (2005). Islam in Southeast Asia: Political, Social and Strategic Challenges for the $21^{\text {st }}$ Century. Singapore: Institute of Southeast Asian Studies.

Ricklefs, M.C.. (2001). a History of Modern Indonesia since c.1200. edisi 3. London: Palgrave.

Sewang, Ahmad M.. (2005). Islamisasi Kerajaan Gowa: Abad XVI sampai Abad XVII. Jakarta: Yayasan Obor Indonesia.

Sihbudi, Riza (ed). (2000). Problematika Minoritas Muslim di Asia Tenggara. Jakarta: Puslitbang Politik dan Kewilayahan, LIPI.

Suryanegara, Ahmad Mansur. (1998). Menemukan Sejarah : Wacana Pergerakan Islam di Indonesia. Jakarta: Mizan. 